\title{
Respon Tanaman Cabai Rawit (Capsicum frutescens L.) Varietas Pelita F1 terhadap Penggenangan
}

\author{
Response of Cayenne Pepper (Capsicum frutescens L.) Pelita F1 Varieties to flooding \\ RR Pascalina Raras, Endang Saptiningsih*, Sri Haryanti \\ Program Studi Biologi Fakultas Sains dan Matematika Universitas Diponegoro Semarang \\ *Email: saptiningsihe@yahoo.co.id
}

Diterima 21 Februari 2021 / Disetujui 26 April 2021

\begin{abstract}
ABSTRAK
Cabai rawit (Capsicum frutescens L.) merupakan salah satu tanaman yang memiliki nilai ekonomi tinggi dan daya adaptasi yang cukup luas. Curah hujan tinggi di Indonesia mengakibatkan lahan tergenang sehingga mengancam produktivitas tanaman, salah satunya cabai rawit. Tujuan penelitian ini untuk mengetahui respon dan toleransi tanaman cabai rawit ( $C$. frutescens $\mathrm{L}$.) varietas Pelita F1 terhadap penggenangan. Perlakuan terdiri dari kontrol (kapasitas lapang) dan perlakuan penggenangan selama 24 jam. Perlakuan menggunakan 2 atau 3 ulangan. Desain penelitian menggunakan RAL dan analisis data menggunakan ANOVA dan uji lanjut LSD taraf signifikan 5\%. Hasil penelitian menunjukkan terjadi penurunan persentase layu, kerusakan ujung akar, penurunan kandungan klorofil a, klorofil $b$, klorofil total dan karotenoid setelah penggenangan. Tanaman terlihat segar, jumlah daun dipertahankan, terjadi pertumbuhan akar, peningkatan kandungan pigmen fotosintesis, tinggi tanaman dan berat kering pada akhir fase pemulihan. Terjadinya pertumbuhan diakhir fase pemulihan menunjukkan cabai varietas Pelita F1 toleran terhadap penggenangan 24 jam. Kemampuan tanaman dalam memperbaiki sistem perakaran, mempertahankan jumlah daun dan meningkatkan kandungan pigmen fotosintesis merupakan faktor penting dalam toleransi tanaman terhadap penggenangan.
\end{abstract}

Kata kunci : penggenangan, periode pemulihan, layu, pigmen fotosintesis, toleransi

\begin{abstract}
Cayenne pepper (Capsicum frutescens L.) has a high economic value and broad adaptability. High rainfall in Indonesia resulted in flooding that threatened crop productivity, one of which is cayenne pepper. This study aimed to determine the response and tolerance of cayenne pepper ( $C$. frutescens L.) Pelita F1 varieties to flooding. The treatments consisted of control and flooding treatment for 24 hours. The treatment using 2 or 3 replications. Research design using CRD and data analysis using ANOVA and LSD advanced test with a significant level of 5\%. The results showed a decrease in the percentage of wilt, root tip damage, decreased content of chlorophyll a, chlorophyll b, total chlorophyll, and carotenoids after flooding. Plants look fresh, the number of leaves is maintained, root growth occurs, an increase in the content of photosynthetic pigments, plant height, and dry weight at the end of the recovery phase. The occurrence of growth at the end of the recovery phase showed that the Pelita F1 variety was tolerant of 24 hours of flooding. The ability of plants to improve root systems, maintain leaf number and increase the content of photosynthetic pigments are essential factors in plant tolerance to flooding.
\end{abstract}

Keywords: flooding, recovery period, wilting, photosynthetic pigments, tolerance 


\section{PENDAHULUAN}

Sebagian besar tanaman cabai rawit dapat tumbuh di dataran rendah hingga dataran tinggi. Tanaman cabai rawit juga dapat ditanam pada lahan kering maupun lahan sawah. Tanaman cabai di lahan kering biasanya ditanam menjelang musim hujan, sedangkan di sawah menjelang musim kemarau (Anwarudin et al, 2015). Salah satu permasalahan yang kerap muncul di Indonesia adalah curah hujan yang tergolong tinggi, yaitu berkisar antara 700-3.000 mm/tahun (Mamenun et $a l, 2014)$. Curah hujan tersebut dapat menyebabkan banjir di lahan-lahan pertanian sehingga menyebabkan penurunan produktivitas hasil pertanian, salah satunya cabai rawit (Avivi et al., 2015).

Banjir dan pengelolaan drainase yang buruk menyebabkan penggenangan (Ezin et al, 2010). Penggenangan merupakan salah satu cekaman abiotik yang menurunkan pertumbuhan dan produktivitas tanaman (Rujito et al, 2012). Penggenangan selama beberapa periode dapat mengubah sifat kimiawi, mikrobiologi, dan ketersediaan hara dalam tanah. Penggenangan tersebut mempengaruhi keberadaan dan aktivitas mikrobia yang berada di dalam tanah. Aktivitas mikrobia tanah sangat menentukan tingkat ketersediaan hara dan produktivitas tanah (Rachmawati dan Retnaningrum, 2013). Penggenangan menimbulkan beberapa respon pada tanaman, antara lain: layu, gugur daun, perkembangan aerenkim pada korteks akar, terbentuknya akar adventif, penurunan kandungan klorofil, penghambatan pertumbuhan tanaman, serta penurunan berat basah dan berat kering (Avivi et al, 2018). Tumbuhan merespon kondisi tergenang melalui penyesuaian dalam pertumbuhan, akumulasi dan alokasi biomassa, modifikasi anatomi serta morfologi pada akar, batang dan daun (Oliveira et al, 2015).

Pratama dan Lestari (2019) melaporkan bahwa penggenangan beberapa genotype bayam selama 2 hari tidak mengakibatkan terhambatnya pertumbuhan tanaman. Sebaliknya pada tanaman gandum Jepang yang digenangi 2 hari dilaporkan mengalami reduksi pertumbuhan akar dan terjadi pembentukan aerenkima, namun tanaman tetap tumbuh walaupun pertumbuhannya terhambat (Haque et al., 2012). Penggenangan pada cabai varietas Bravo dan Laris selama 3 hari dilaporkan menyebabkan daun klorosis, gugur, pertumbuhan terhenti dan akhirnya mati (Susilawati et al., 2012). Dilaporkan juga penggenangan selama 1 hari pada 3 varietas cabai rawit yaitu Cakra Hijau, Sret, dan Mhanu XR mengakibatkan layu dan kematian tanaman (Pahlevi et al., 2019). Berbagai jenis dan varietas tanaman budidaya menunjukkan respon yang berbeda terhadap penggenangan. Eksplorasi varietas-varietas cabai tahan penggenangan sangat diperlukan dalam mendukung budidaya dan ketersediaan cabai selama perubahan iklim saat ini. Salah satu varietas cabai rawit yang telah dilepas di pasaran adalah varietas Pelita F1. Kajian terkait respon cabai varietas Pelita F1 terhadap penggenangan belum banyak dilaporkan sehingga perlu dilakukan kajian terhadap varietas tersebut. Penelitian ini bertujuan untuk mengkaji respon dan toleransi tanaman cabai rawit varietas Pelita F1 terhadap penggenangan selama 24 jam.

\section{METODE PENELITIAN}

Penelitian menggunakan tanaman cabai rawit (Capsicum frutescens .L) varietas Pelita F1 yang didapatkan dari PT Trubus Semarang. Penelitian dilaksanakan di Greenhouse yang berlokasi di Ungaran (Dusun Sikebrok, Kelurahan Beji, Ungaran Timur), Laboratorium BSFT Universitas Diponegoro Semarang dan UPT Laboratorium Terpadu Universitas Diponegoro Semarang.

Penelitian ini dilakukan dengan cara benih disemai pada media tanam berupa pasir sungai. Ketika semai berusia \pm 2 minggu dipindahkan ke pot diameter $15 \mathrm{~cm}$ dan tinggi $10 \mathrm{~cm}$ yang berisi media tanam berupa pasir sungai. Perlakuan berupa penggenangan selama 24 jam dan kontrol (kapasitas lapang) dilakukan pada saat tanaman berusia \pm 2 bulan atau pada fase vegetatif akhir. Tanaman dalam pot dimasukkan kontainer plastik kemudian digenangi air sampai $\pm 5 \mathrm{~cm}$ di atas permukaan media tanam. Setelah 24 jam digenangi, selanjutnya tanaman dikeluarkan dari kontainer dan dibiarkan hingga kondisi kapasitas lapang. Perawatan tanaman setelah penggenangan dan selama fase pemulihan berupa penyiraman, pemupukan, 
penyiangan, pendangiran dan pemberian pestisida.

Dilakukan pengamatan terhadap parameter penelitian setelah penggenangan durasi 24 jam dan setelah 4 minggu fase pemulihan. Penelitian menggunakan Rancangan Acak Lengkap (RAL) satu faktor yaitu durasi penggenangan 24 jam. Digunakan 2 ulangan untuk parameter jumlah daun, tinggi tanaman dan berat kering serta 3 ulangan untuk parameter kandungan pigmen fotosintesis

\section{Persentase layu dalam durasi penggenangan 24 jam}

Pengamatan dilakukan tiap 4 jam yaitu pada jam ke-0, ke-4, ke-8, ke-12, ke-16, ke-20 dan ke-24. Persentase layu kemudian dihitung menggunakan rumus:

Persentase layu $=\frac{\text { jumlah tanaman layu }}{\text { jumlah total tanaman }} \times 100 \%$

\section{Pengukuran kandungan pigmen klorofil dan karotenoid}

Pengukuran kandungan pigmen fotosintesis meliputi klorofil a, klorofil b, klorofil total dan karotenoid digunakan daun yang telah masak secara fisiologis sebesar 0,1 gram. Selanjutnya diekstrasi dengan nitrogen cair dan aseton $80 \%$ untuk mendapatkan filtrat. Filtrat kemudian dianalisis menggunakan spektrofotometer UV-VIS UH5300 pada panjang gelombang $470 \mathrm{~nm}, 646 \mathrm{~nm}$ dan 663 nm. Kandungan klorofil dan karotenoid dihitung berdasarkan Wellburn (1994).

$$
\begin{aligned}
\text { Klorofil a } & =12,21\left(\mathrm{~A}_{663}\right)-2,81\left(\mathrm{~A}_{646}\right) \\
\text { Klorofil } \mathrm{b} & =20,13\left(\mathrm{~A}_{646}\right)-5,03\left(\mathrm{~A}_{663}\right) \\
\text { Klorofil total } & =\mathrm{C}_{\mathrm{a}}+\mathrm{C}_{\mathrm{b}} \\
\text { Karotenoid } & =\left(1000 \mathrm{~A}_{470}-3,27 \mathrm{C}_{\mathrm{a}}-\right. \\
& \left.104 \mathrm{C}_{\mathrm{b}}\right) / 198
\end{aligned}
$$

\section{Peningkatan tinggi tanaman}

Pengukuran tinggi tanaman diukur dari pangkal batang di atas tanah sampai percabangan terakhir di ujung batang. Tinggi tanaman diukur sebelum penggenangan dan setelah 4 minggu fase pemulihan. Pengukuran persentase peningkatan tinggi tanaman dihitung menggunakan rumus:

Persentase peningkatan tinggi $=$ $\frac{\text { (tinggi akhir-tinggi awal) }}{\text { tinggi awal }} \times 100 \%$

\section{HASIL DAN PEMBAHASAN}

\section{Persentase Layu pada Durasi Penggenangan 24 Jam}

Persentase kelayuan pada penggenangan 4 jam pertama dan kedua mengalami peningkatan dari $62,5 \%$ menjadi $87,5 \%$. Persentase kelayuan pada penggenangan 4 jam ketiga, keempat dan kelima mengalami pola stasioner, selanjutnya persentase kelayuan pada penggenangan 4 jam terakhir mengalami penurunan sampai 0\% (Gambar 1). Layu pada tajuk tanaman selama periode penggenangan maupun setelah periode penggenangan merupakan gejala kekurangan oksigen di daerah perakaran sehingga mengakibatkan perubahan metabolisme meliputi penurunan aktivitas aquaporin dan konduktivitas akar (Pahlevi et al., 2019). Dampak selanjutnya adalah penurunan penyerapan dan transport air menuju tajuk sehingga mengakibatkan layu. Hasil penelitian menunjukkan kondisi layu terjadi pada periode penggenangan 4 jam sampai 20 jam, namun persentase layu mengalami penurunan drastis setelah durasi penggenangan 20 hingga 24 jam. Hal ini menunjukkan tanaman cabai mampu mengatasi cekaman penggenangan setelah durasi 24 jam. Daun pada tajuk yang tegak dan segar kembali menunjukkan bahwa transport air kembali normal di akhir periode penggenangan. Kondisi ini terjadi karena akar tanaman mampu menyesuaikan metabolismenya sehingga perolehan tenaga atau ATP dapat berlangsung dan aktivitas aquaporin serta konduktivitas akar dapat dipertahankan (Patel et al., 2014). Tingkat kelayuan pada penelitian ini juga menunjukkan tanaman cabai toleran terhadap durasi penggenangan 24 jam karena persentase kelayuan setelah fase pemulihan mencapai $0 \%$. Palupi dkk. (2015), melaporkan bahwa tanaman yang tahan penggenangan mengalami kelayuan dibawah $11 \%$. Pada toleransi tomat hibrida hasil dari metode sambung batang juga dilaporkan tingkat kelayuan mencapai $0 \%$ setelah fase pemulihan (Bahadur et al., 2015). 


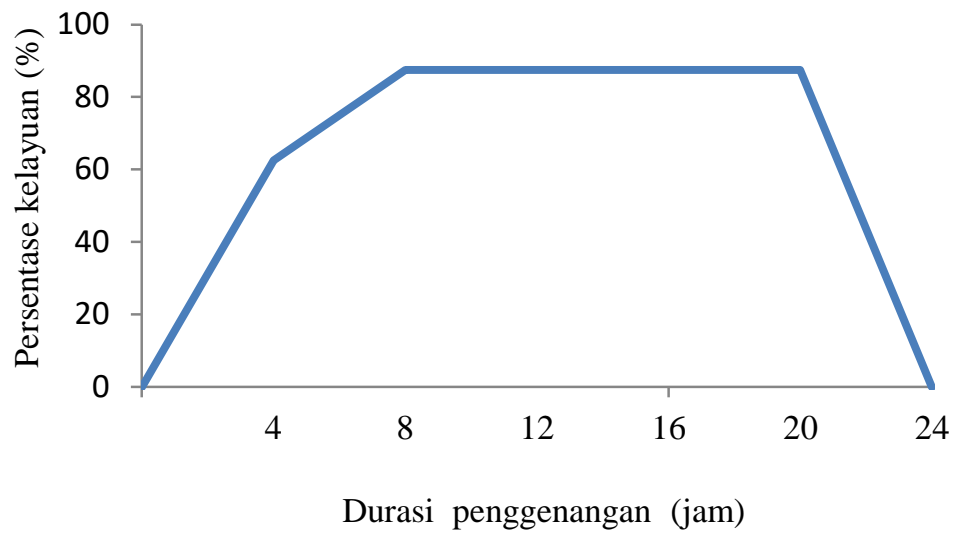

Gambar 1. Persentase layu selama durasi penggenangan 24 jam

\section{Pengukuran Kandungan Pigmen Klorofil dan Karotenoid}

Berdasarkan analisis pigmen fotosintesis, durasi penggenangan 24 jam berpengaruh nyata $(\mathrm{P}<0,05)$ terhadap kandungan klorofil a, klorofil $\mathrm{b}$, klorofil total dan karotenoid setelah penggenangan (Gambar 2) maupun setelah fase pemulihan (Gambar 3). Kandungan pigmen fotosintesis mengalami penurunan dibandingkan kontrol setelah penggenangan, namun kandungan pigmen lebih tinggi diakhir fase pemulihan. Kandungan pigmen fotosintesis pada perlakuan penggenangan menunjukkan pola peningkatan diakhir fase pemulihan dibandingkan kandungan pigmen fotosintesis setelah penggenangan. Kandungan pigmen fotosintesis tertinggi terdapat pada klorofil a.

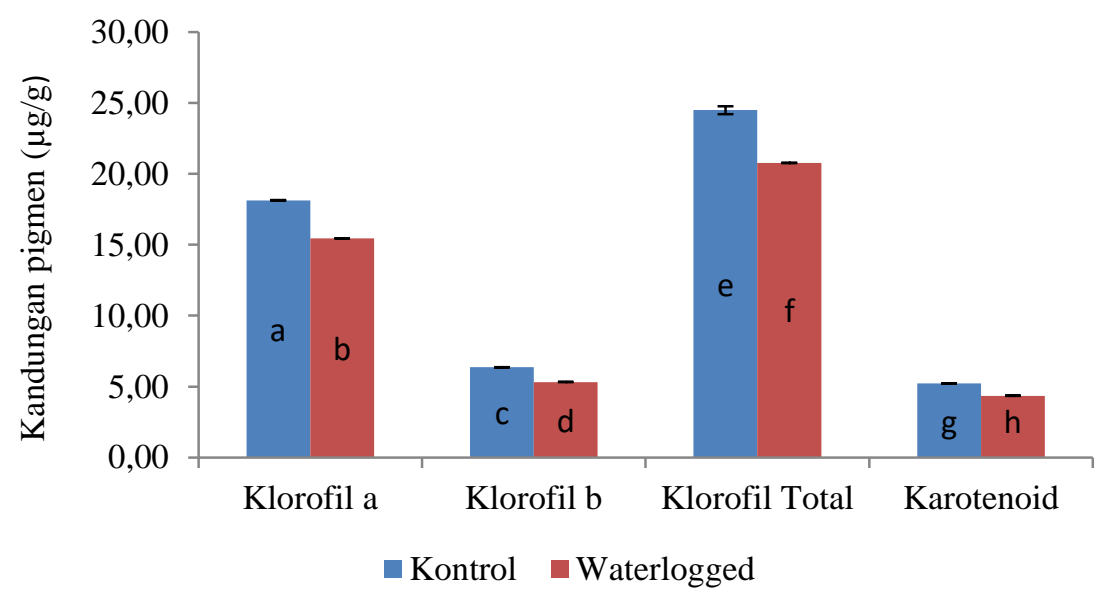

Gambar 2. Kandungan pigmen fotosintesis setelah periode penggenangan 24 jam. Garis bar menunjukkan nilai $\mathrm{SD}(\mathrm{n}=3)$.

Cekaman biotik maupun cekaman abiotik dapat mempengaruhi kandungan pigmen fotosintesis (Park et al., 2020; Ulya dkk., 2020). Beberapa penelitian terkait kandungan pigmen fotosintesis selama penggenangan telah dilapokan. Penggenangan pada Vigna radiata tidak mempengaruhi kandungan klorofil daun (Kumar et al., 2013). Tanaman dapat melakukan adaptasi terhadap penggenangan melalui peningkatan antioksidan sehingga aktivitas ROS dan kerusakan klorofil dapat ditekan. Amri et al. (2014), melaporkan kemampuan mempertahankan kandungan klorofil terjadi pada kultivar gandum yang toleran terhadap penggenangan. Hal yang sama juga dilaporkan pada sweetpotato bahwa kultivar yang toleran menunjukkan peningkatan 
aktivitas antioksidan dan terjaganya integritas membran sehingga kandungan klorofil tetap tinggi dalam kondisi cekaman penggenangan (Park et al., 2020). Pada kajian ini terlihat bahwa kandungan pigmen fotosintesis mengalami penurunan setelah penggenangan. Penggenangan mengakibatkan akumulasi ROS dan peningkatan aktivitas enzim chlorophyllase yang menginduksi kerusakan pigmen (Ella et al., 2003). Kemungkinan tanaman mampu meningkatkan aktivitas antioksidan di organ daun selama fase pemulihan sehingga kandungan pigmen fotosintesis dapat ditingkatkan diakhir fase pemulihan.

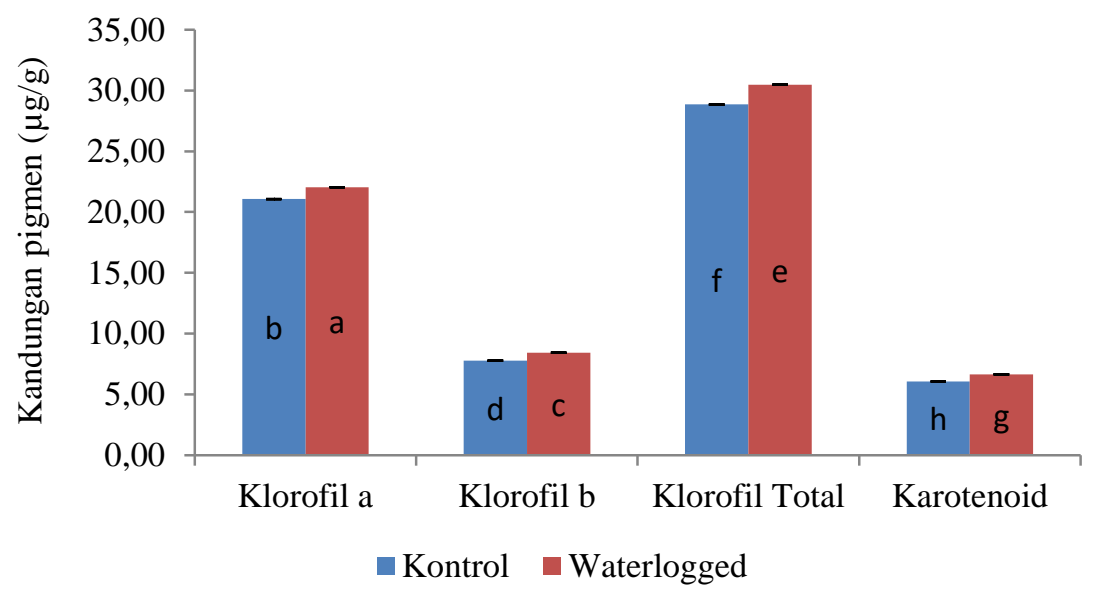

Gambar 3. Kandungan pigmen fotosintesis setelah fase pemulihan. Garis bar menunjukkan nilai SD $(n=3)$.

\section{Peningkatan tinggi tanaman}

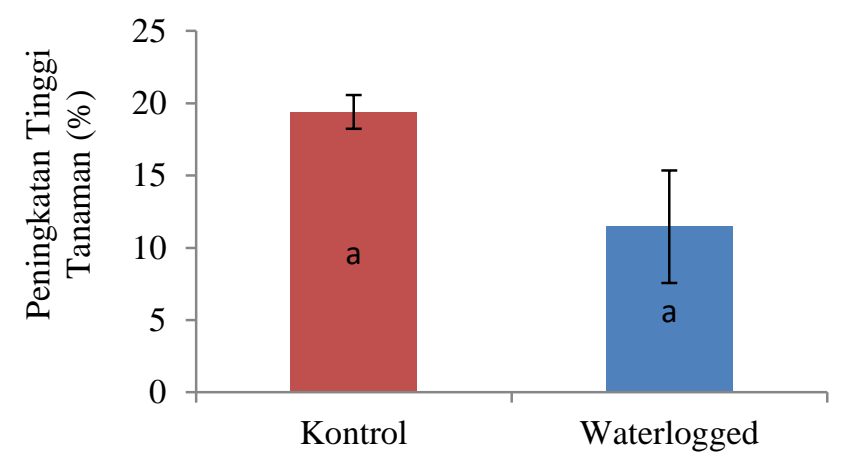

Gambar 4. Peningkatan tinggi tanaman di akhir fase pemulihan. Garis bar menunjukkan nilai SD $(n=2)$.

Berdasarkan pengamatan dan hasil uji MannWhitney di akhir fase pemulihan menunjukkan bahwa penggenangan tidak berpengaruh secara signifikan $(\mathrm{P}>0,05)$ terhadap persentase peningkatan tinggi tanaman (Gambar 4). Peningkatan tinggi tanaman menunjukkan terjadinya proses pertumbuhan. Beberapa jenis tanaman menunjukkan respon yang berbeda terkait peningkatan tinggi tanaman pada kondisi tergenang. Dilaporkan pada tanaman Styrax pohlii tidak terjadi peningkatan pertumbuhan selama fase pemulihan, hal ini merupakan respon tanaman dalam mempertahankan laju metabolisme rendah untuk penghematan energi (Kissmann et al., 2014). Pada Jatropha curcas dilaporkan terjadi peningkatan tinggi tanaman sebesar 3\% setelah fase pemulihan, hal ini terkait dengan peningkatan pertumbuhan akar, jumlah daun dan luas daun, konduktivitas stomata, laju fotosintesis dan transpirasi (Verma et al., 2014). Hasil yang sama juga ditunjukkan pada penelitian ini bahwa terjadi peningkatan tinggi tanaman selama fase pemulihan 
yang didukung oleh pertumbuhan akar, kemampuan mempertahankan jumlah daun dan peningkatan kandungan pigmen fotosintesis. Parad et al. (2016), menyatakan bahwa tanaman yang toleran terhadap penggenangan menghasilkan ATP yang lebih banyak sehingga produksi hormon tanaman seperti giberelin dan sitokinin mencukupi untuk melakukan pembelahan dan pemanjangan sel selama pertumbuhan.

\section{Berat Kering}

Hasil penelitian menunjukkan berat kering tajuk, akar dan berat kering total tidak berbeda secara signifikan pada uji Mann-Whitney $(\mathrm{P}>0,05)$ setelah periode penggenangan 24 jam (Gambar 5) dan setelah fase pemulihan (Gambar 6).

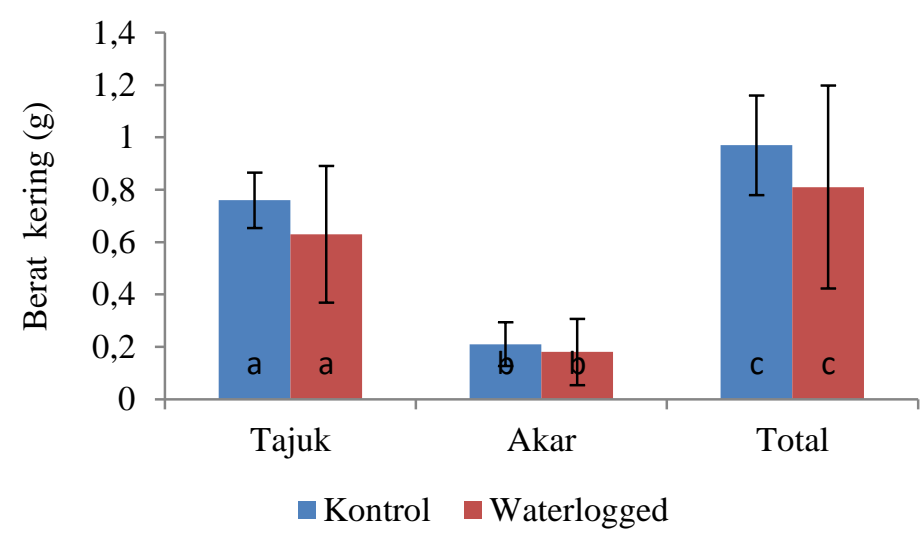

Gambar 5. Berat kering setelah periode penggenangan 24 jam. Garis bar menunjukkan nilai SD $(n=2)$.

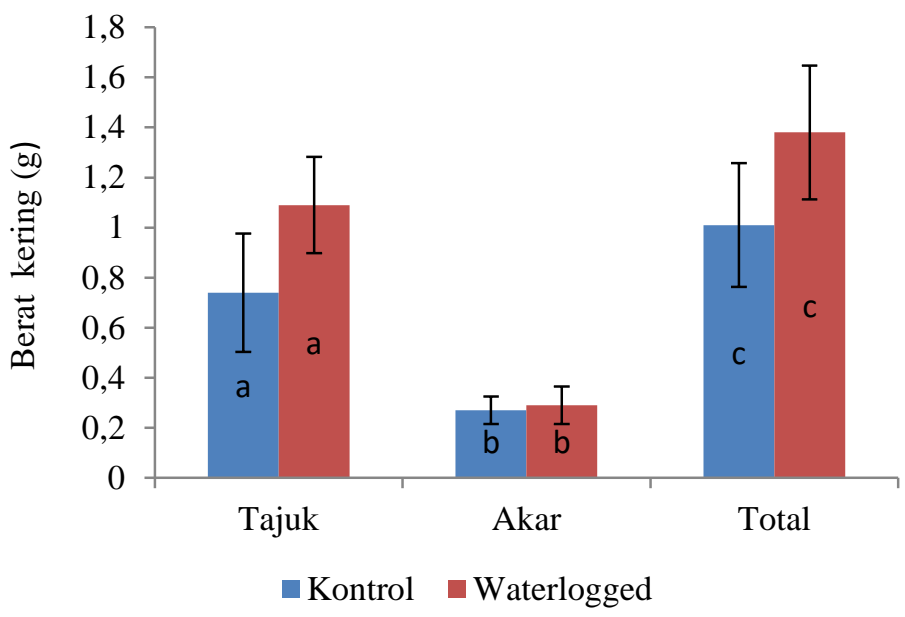

Gambar 6. Berat kering setelah fase pemulihan. Garis bar menunjukkan nilai SD $(n=2)$.

Berat kering merupakan hasil penimbunan bersih asimilasi $\mathrm{CO}_{2}$ yang dilakukan selama pertumbuhan dan perkembangan tanaman. Umumnya penggenangan mengakibatkan penurunan berat kering tanaman dalam berbagai fase pertumbuhan (Kaur et al., 2020). Penggenangan mengakibatkan penurunan drastis ATP, kerusakan akar, penurunan penyerapan air dan hara, penurunan konduktansi stomata, fiksasi $\mathrm{CO}_{2}$, laju fotosintesis sehingga mengakibatkan penurunan akumulasi biomassa (Liu et al., 2014). Beberapa species tanaman yang toleran mengembangkan adaptasinya melalui perubahan morfologis, fisiologis dan biokimia sehingga fungsi akar, laju fotosintesis dan ketersediaan sumber energi dapat dipertahankan (Argus et al., 2015). 
Pada penelitian ini terlihat bahwa cabai varietas Pelita F1 mampu mempertahankan berat kering tanaman setelah penggenangan dan meningkatkan berat kering diakhir fase pemulihan. Nampaknya kemampuan menumbuhkan akar, mempertahankan jumlah daun dan meningkatkan kandungan pigmen fotosintesis mendukung peningkatan berat kering di akhir fase pemulihan.

\section{Deskripsi Morfologi Akar}
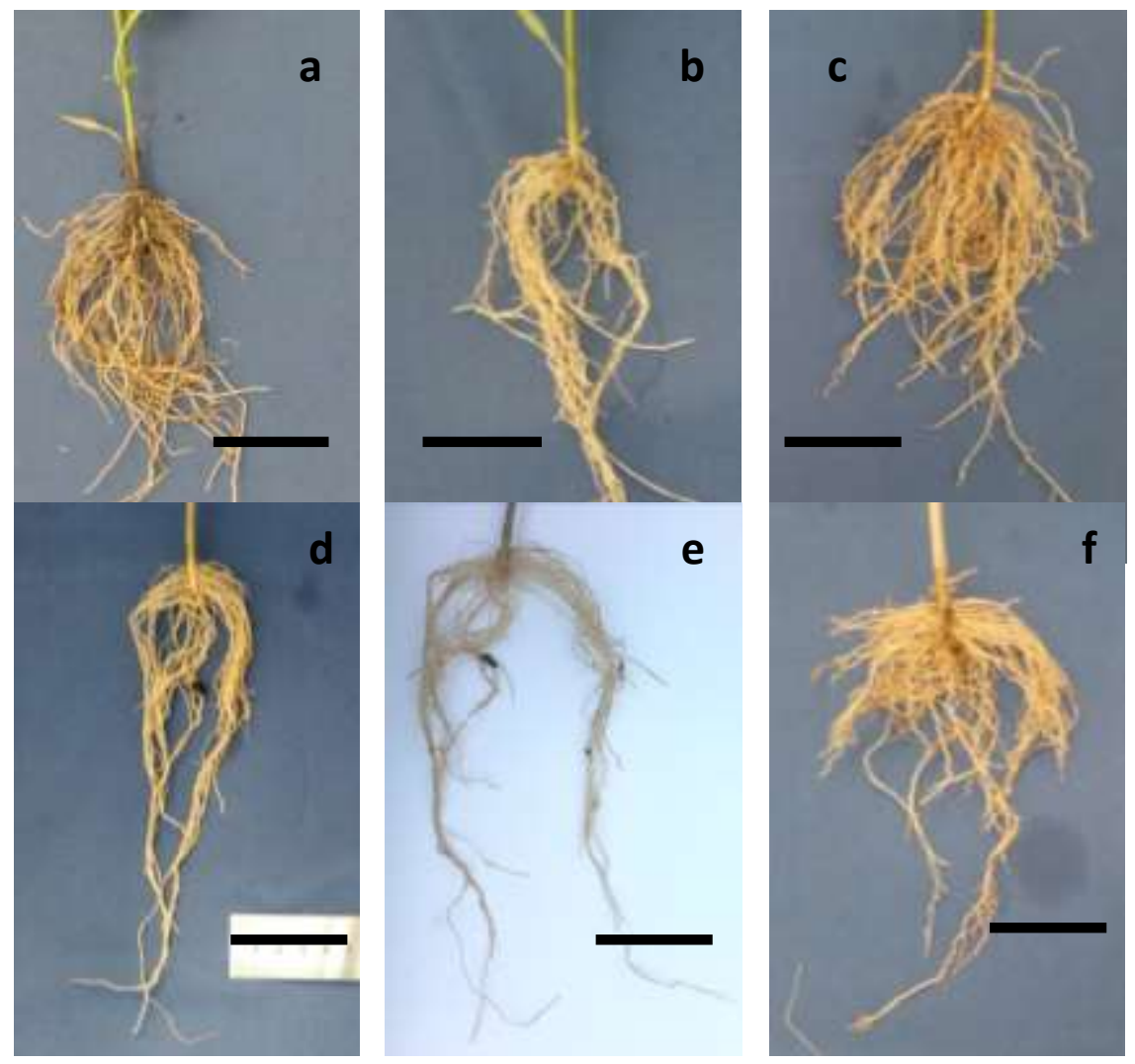

Gambar 7. Morfologi akar. Kontrol sebelum penggenangan (a), kontrol setelah penggenangan durasi 24 jam (b), kontrol setelah fase pemulihan 4 minggu (c), perlakuan flooding sebelum penggenangan (d), perlakuan flooding durasi 24 jam (e), perlakuan flooding setelah fase pemulihan (f). $B a r=5 \mathrm{~cm}$

Penggenangan menyebabkan beberapa perubahan morfologi pada akar (Gambar 2). Akar tanaman yang terendam selama 24 jam mengalami pembusukan $2 \mathrm{~mm}$ dari ujung akar yang ditandai dengan akar menjadi berwarna hitam, sementara tanaman kontrol akarnya masih segar dan lebat serta berwarna putih kekuningan. Setelah 4 minggu fase pemulihan, akar tanaman perlakuan penggenangan tetap tumbuh namun di beberapa ujungnya rusak, sementara akar tanaman perlakuan kontrol tumbuh lebat dengan warna putih kekuningan. Salah satu dampak penggenangan adalah kerusakan dan pembusukan akar (Striker dan Colmer, 2017; Pahlevi et al., 2019). Kerusakan, pembusukan dan hambatan pertumbuhan akar disebabkan oleh adanya krisis energi, akumulasi $\mathrm{CO}_{2}$ dan etilen serta reactive oxygen species (ROS) pada sistem perakaran (Voesenek dan BaileySerres, 2015). Berdasarkan hasil penelitian menunjukkan akar mampu tumbuh kembali pada fase pemulihan setelah sebagian ujung akar membusuk selama penggenangan. Hal ini juga menunjukkan bahwa tanaman mampu mengatasi kondisi cekaman melalui adaptasi terhadap ketersediaan energi rendah, meningkatkan aliran dan kandungan $\mathrm{O}_{2}$ di akar serta meningkatkan sistem pertahanan terhadap ROS sehingga kerusakan akar dapat ditekan dan fungsi akar dapat 
dipertahankan. Tingkat kerusakan akar rendah mendukung kecepatan pertumbuhan akar selama fase pemulihan. Di akhir fase pemulihan terlihat peningkatan pertumbuhan akar, terutama di daerah dekat pangkal batang.

\section{KESIMPULAN}

Tanaman cabai rawit varietas Pelita F1 toleran terhadap penggenangan selama 24 jam yang ditunjukkan dengan respon pertumbuhan tanaman diakhir fase pemulihan. Kajian terkait eksplorasi ketahanan tanaman cabai terhadap penggenangan dapat dikembangkan. Peningkatan durasi penggenangan, mekanisme adaptasi tanaman dan aktivitas antioksidan dapat dikaji lebih lanjut.

\section{UCAPAN TERIMA KASIH}

Penelitian ini terlaksana atas dukungan Program Universitas Diponegoro dalam Riset Pengembangan dan Pelaksanaan (RPP) Sumber Dana Selain APBN 2020 dengan Kontrak Nomor 233-108 / UN7.6.1 / PP / 2020.

\section{DAFTAR PUSTAKA}

Ali, M. 2015. Pengaruh Dosis Pemupukan NPK Terhadap Produksi dan Kandungan Capsaicin Pada Buah Tanaman Cabai Rawit (Capsicum frutescens .L). Jurnal Agrosains. Vol 2 No 2: 171-178.

Amri, M., El Ouni, M. H., \& Salem, M. B. .2014. Waterlogging Affect the Development, Yield and Components, Chlorophyll Content and Chlorophyll Fluorescence of Six Bread Wheat Genotypes (Triticum aestivum L.). Bulg. J. Agric. Sci. Vol 20 No 3: 647-657.

Anwarudin J, Sayekti A, Marendra A, dan Hilman Y. 2015. Dinamika Produksi dan Volatilitas Harga Cabai: Antisipasi Strategi dan Kebijakan Pengembangan. Jurnal Pengembangan Inovasi Pertanian. Vol 8 No 1: 33-42.

Argus, R. E., Colmer, T. D., \& Grierson, P. F. 2015. Early Physiological Flood Tolerance is Followed by Slow Post-Flooding Root Recovery in the Dryland Riparian Tree Eucalyptus camaldulensis subsp. Refulgens.
Plant, Cell \& Environmen. Vol 38 No 6: 1189-1199.

Avivi S., Syamsunihar A., dan Soeparjono. 2018. Toleransi Berbagai Varietas Tebu Terhadap Penggenangan Pada Fase Bibit Berdasarkan Karakter Morfologi dan Anatomi. J Agron. 46(1): 103-110.

Bahadur, A., Rai, N., Kumar, R., Tiwari, S. K., Singh, A. K., Rai, A. K., Singh, U., Patel, P.K., Tiwari, V., Rai, A.B., Singh, M \& Singh, B. 2015. Grafting Tomato on Eggplant as a Potential Tool to Improve Waterlogging Tolerance in Hybrid Tomato. Vegetable Science. Vol 42 No 2: 82-87.

Ella, E. S., Kawano, N., Yamauchi, Y., Tanaka, K., \& Ismail, A. M. 2003. Blocking Ethylene Perception Enhances Flooding Tolerance in Rice Seedlings. Functional Plant Biology. Vol 30 No 7: 813-819.

Ezin V., de la Pena R., and Ahanchede A. 2010. Flooding Tolerance of Tomato Genotypes During Vegetative and Reproductive Stages. Brazilian Journal of Plant Physiology. Vol 22 No 2: 131-142.

Haque E., Oyanagi A., and Kawaguchi K. 2012. Aerenchyma Formation in the Seminal Roots of Japanese Wheat Cultivars in Relation to Growth Under Waterlogged Conditions. Taylor \& Francis: Plant Production Science. Vol 15 No 3: 164-173.

Kaur, G., Singh, G., Motavalli, P. P., Nelson, K. A., Orlowski, J. M., \& Golden, B. R. 2020. Impacts and Management Strategies for Crop Production in Waterlogged or Flooded Soils: A review. Agronomy Journal. Vol 112 No 3: 1475-1501.

Kissmann, C., da Veiga, E. B., Eichemberg, M. T., \& Habermann, G. 2014. Morphological Effects of Flooding on Styrax pohlii and the Dynamics of Physiological Responses During Flooding and Post-Flooding Conditions. Aquatic Botany. Vol 119: 7-14.

Kumar P. et al. 2013. Yield, Growth and Physiological Response of Mung Bean (Vigna radiata) Genotypes of Waterlogging at Vegetative Stage. Physiol Mol Biol Plants. Vol 19 No 2: 209-220. 
Liu, Z., Cheng, R., Xiao, W., Guo, Q., \& Wang, N. 2014. Effect of Off-Season Flooding on Growth, Photosynthesis, Carbohydrate Partitioning, and Nutrient Uptake in Distylium chinense. PloS one. Vol 9 No 9: e107636.

Mamenun, Pawitan .H, dan Ardhasena. 2014. Validasi dan Koreksi Data Satelit TRMM pada Tiga Pola Hujan di Indonesia. Jurnal Meteorologi dan Geofisika. Vol 15 No 1: 1323.

Oliveira A, Ferreira C, Ribeiro D, and Franco A. 2015. Anatomical and Morphological Modifications in Response to Flooding by Six Cerrado Tree Species. Acta Botanica Brasilica. 29(4): 478-488.

Pahlevi, M. R., Indriyani, S., Mastuti, R., \& Arumingtyas, E. L. 2019. Flooding Effect to Capsicum frutescens L. in Wilting and Death Perspectives. AIP Conference Proceedings. Vol. 2120 No. 1: 030010.

Palupi, H., Yulianah, I., \& Respatijarti, R. 2015. Uji Ketahanan 14 Galur Cabai Besar (Capsicum annuит L.) terhadap Penyakit Antraknosa (Colletotrichum spp) dan Layu Bakteri (Ralstonia solanacearum). Jurnal Produksi Tanaman, 3(8).

Parad, G. A., Kouchaksaraei, M. T., Striker, G. G., Sadati, S. E., \& Nourmohammadi, K. 2016. Growth, morphology and gas exchange responses of two-year-old Quercus castaneifolia seedlings to flooding stress. Scandinavian Journal of Forest Research. 31(5): 458-466.

Park, S. U., Lee, C. J., Kim, S. E., Lim, Y. H., Lee, H. U., Nam, S. S., Kim, H.S. \& Kwak, S. S. 2020. Selection of Flooding Stress Tolerant Sweet Potato Cultivars Based on Biochemical and Phenotypic Characterization. Plant Physiology and Biochemistry. Vol 155: 243-251.

Patel, P. K., Singh, A. K., Tripathi, N., Yadav, D., \& Hemantaranjan, A. 2014. Flooding: Abiotic Constraint Limiting Vegetable Productivity. Advances in Plants and Agriculture Research. Vol 1 No 3: 96-103.
Pratama, M. dan Lestari S. 2019. Keragaman Beberapa Genotipe Bayam (Amaranthus tricolor .L) Terhadap Cekaman Genangan. Jurnal Produksi Tanaman. Vol 7 No 6: 11211129.

Rachmawati, D dan Retnaningrum, E. 2013. Pengaruh Tinggi dan Lama Penggenangan Terhadap Pertumbuhan Padi Kultivar Sintanur dan Dinamika Populasi Rhizobakteri Pemfiksasi Nitrogen Non Simbiosis. Bionatura. Vol 15 No 2: 117-125.

Rujito A, Susilawati, Munandar, dan Hasmeda. 2012. Karakter Agronomi dan Fisiologi Varietas Cabai Merah pada Kondisi Cekaman Genangan. Jurnal Agron Indonesia. Vol 40(3): 196-203.

Striker, G. G., \& Colmer, T. D. 2017. Flooding Tolerance of Forage Legumes. Journal of Experimental Botany. Vol 68 No 8: 18511872.

Susilawati, R.A Suwignyo, Munandar dan Hasmeda. 2012. Karakter Agronomi dan Toleransi Varietas Cabai Merah Akibat genangan pada Fase Generatif. Journal of Suboptimal Lands. Vol 1 No 1: 22-30.

Tsurayya, S dan Kartika L. 2015. Kelembagaan dan Strategi Peningkatan Daya Saing Komoditas Cabai Kabupaten Garut. Jurnal Manajemen \& Agribisnis. Vol 12 No 1: 1-13.

Ulya, H., Ferniah, R. S., \& Darmanti, S. 2020. Respons Fisiologi Tanaman Cabai (Capsicum annuum) Var. Lembang 1 Terhadap Infeksi Fusarium oxysporum pada Umur Tanaman yang Berbeda. Buletin Anatomi dan Fisiologi (Bulletin of Anatomy and Physiology), 5(2).

Verma, K. K., Singh, M., Gupta, R. K., \& Verma, C. L. 2014. Photosynthetic Gas Exchange, Chlorophyll Fluorescence, Antioxidant Enzymes, and Growth Responses of Jatropha curcas During Soil Flooding. Turkish Journal of Botany. Vol 38 No 1: 130140.

Voesenek, L. A., \& Bailey-Serres, J. 2015. Flood Adaptive Traits and Processes: an Overview. New Phytologist. Vol 206 No 1: 57-73. 
Wellburn, A. R. 1994. The Spectral Determination of Chlorophylls a and b, as Well as Total Carotenoids, Using Various Solvents with Spectrophotometers of Different Resolution. Journal Plant Physiology. 144(3): 307-313. 